\title{
Prostaglandin E2 receptors in asthma and in chronic rhinosinusitis/nasal polyps with and without aspirin hypersensitivity
}

\author{
Liliana Machado-Carvalho ${ }^{1,2,3^{*}}$, Jordi Roca-Ferrer ${ }^{1,2,3}$ and César Picado ${ }^{1,2,3}$
}

\begin{abstract}
Chronic rhinosinusitis with nasal polyps (CRSwNP) and asthma frequently coexist and are always present in patients with aspirin exacerbated respiratory disease (AERD). Although the pathogenic mechanisms of this condition are still unknown, AERD may be due, at least in part, to an imbalance in eicosanoid metabolism (increased production of cysteinyl leukotrienes (CysLTs) and reduced biosynthesis of prostaglandin (PG) $E_{2}$ ), possibly increasing and perpetuating the process of inflammation. $\mathrm{PGE}_{2}$ results from the metabolism of arachidonic acid (AA) by cyclooxygenase (COX) enzymes, and seems to play a central role in homeostasis maintenance and inflammatory response modulation in airways. Therefore, the abnormal regulation of $\mathrm{PGE}_{2}$ could contribute to the exacerbated processes observed in AERD. $\mathrm{PGE}_{2}$ exerts its actions through four G-protein-coupled receptors designated E-prostanoid (EP) receptors EP1, EP2, EP3, and EP4. Altered PGE 2 production as well as differential EP receptor expression has been reported in both upper and lower airways of patients with AERD. Since the heterogeneity of these receptors is the key for the multiple biological effects of $\mathrm{PGE}_{2}$ this review focuses on the studies available to elucidate the importance of these receptors in inflammatory airway diseases.
\end{abstract}

Keywords: Aspirin exacerbated respiratory disease, Asthma, Chronic rhinosinusitis, Nasal polyps, Prostaglandin $E_{2}$, Prostaglandin $E_{2}$ receptors

\section{Introduction}

The purpose of this review is to offer a global overview of the significant literature available about prostaglandin (PG) $\mathrm{E}_{2}$ receptors in asthma, chronic rhinosinusitis (CRS) and nasal polyposis, with and without aspirin hypersensitivity.

\section{Asthma}

Pathophysiologically, asthma is a multifactorial and complex chronic inflammatory disorder of the lung and is characterized by epithelial disruption, airway smooth muscle hypertrophy and hyperplasia, increased mucus secretion, basement thickening, increased cytokine production and chronic infiltration of inflammatory cells $[1,2]$. Depending on the severity of the disorder, it

\footnotetext{
* Correspondence: Ismachad@clinic.ub.es

${ }^{1}$ Immunoal · lèrgia Respiratòria Clínica i Experimental, CELLEX, Institut d'Investigacions Biomèdiques August Pi i Sunyer (IDIBAPS), Casanova 143, 08036 Barcelona, Spain

${ }^{2}$ Servei de Pneumologia i Al - lèrgia Respiratòria, Hospital Clínic, Universitat de Barcelona, Barcelona, Spain

Full list of author information is available at the end of the article
}

manifests clinically with repeated, variable, and episodic attacks of cough, wheezing and breathlessness [3,4]. The most effective drugs used in asthma control are inhaled corticosteroids. Although recommended and clinically effective in most asthma patients, airway remodelling changes can be resistant to the conventional pharmacological approach [5]. Various factors can trigger and/or develop asthma attacks: allergens, exercise, cold exposure, chemical sensitizers, air pollutants, and respiratory viral infections [3]. Conventionally, classification into atopic and nonatopic asthma is based on the presence or absence of clinical symptoms precipitated by one or more allergens. The presence of allergen-specific antibodies can be identified by skin prick testing or by measuring the level of specific immunoglobulin (Ig) E in serum [6,7].

Airway inflammation in asthma is associated with a massive influx of inflammatory and immune cells within the airways, including eosinophils, $\mathrm{T}$ helper (Th) 2 lymphocytes, mast cells, neutrophils and macrophages. Local overproduction of Th2 cytokines such as interleukin (IL)- 
4, IL-5, IL- 9 and IL-13 by Th2 cells plays an important role in its pathophysiology [6]. IL-4 promotes Th2 cell differentiation, induces IgE production and increases IgE receptors; IL-5 is responsible for promoting eosinophil development, differentiation, recruitment, activation and survival; finally, IL-13 mediates allergen-induced airway hyperresponsiveness [8].

\section{Chronic rhinosinusitis and nasal polyposis}

According to the European Position Paper on Rhinosinusitis (EPOS) [9] rhinosinusitis is defined as an inflammatory process of the nose and the paranasal sinuses characterized by two or more symptoms: nasal blockage/obstruction/ congestion or nasal discharge, as well as facial pain/pressure or reduction/loss of smell [9]. This disorder may be classified into two forms, according to the duration of the symptoms, as acute or chronic [9-11]. In fact, the chronic form that persists beyond 12 weeks without complete resolution is associated with a lower quality of life and constitutes one of the most common health care problems [12]. CRS is subdivided itself into CRS with or without nasal polyps (NPs). Chronic rhinosinusitis with nasal polyps (CRSwNP) is a clinical phenotype found in up to $4 \%$ of the population [13]. The condition consists of loose connective tissue, oedema, inflammatory cells, and some glands and capillaries leading to nasal obstruction, secretion, loss of smell and headache [14]. Although the eosinophils are the most common cells in NPs, other cell types are also present, such as neutrophils, mast cells, plasma cells, lymphocytes, monocytes and fibroblasts $[15,16]$.

\section{Aspirin exacerbated respiratory disease}

Aspirin exacerbated respiratory disease (AERD) is a clinical syndrome characterized by hypersensitivity to aspirin and other non-steroidal anti-inflammatory drugs (NSAIDs), bronchial asthma and CRS with recurrent NPs $[17,18]$. AERD affects $10-20 \%$ of the asthmatic patient population and $8-26 \%$ of those diagnosed with CRSwNP [19]. The ingestion of aspirin or other NSAIDs in these patients provokes bronchoconstriction and exacerbates bronchospasms with attacks of asthma and rhinitis [20]. Effectively the characteristic symptoms of this disorder include moderate to severe asthma, massive eosinophilic infiltration and high prevalence of CRS associated with nasal polyposis [21].

The pathogenic mechanism underlying this disorder is believed to involve, at least in part, alterations in the eicosanoid metabolism and altered eicosanoid receptor expression [22-24]. However, and despite all the efforts, the pathogenicity of AERD is still not fully understood.

\section{Arachidonic acid metabolism}

Arachidonic acid (AA) is a 20-carbon polyunsaturated fatty acid and is the main precursor of eicosanoids, mediating important functions in homeostasis, inflammation and immunoregulation [25]. Under normal conditions AA is not freely available and its concentration within the cell is very low. The availability of free AA is essential for the biosynthesis of eicosanoids. Upon activation of the cell and by the action of various phospholipases (preferentially cytosolic phospholipase $\mathrm{A}_{2}$ ) AA is released from the membrane phospholipids [26]. Therefore, once released, AA is rapidly metabolized through three enzymatic pathways namely cyclooxygenase (COX), lipoxygenase (LO), and cytochrome oxidases (hydrolase, epoxygenase) and one non-enzymatic pathway [27].

\section{Lipoxygenase pathway}

$\mathrm{AA}$, which is esterified on plasma membrane phospholipids, is released and converted into leukotriene (LT) $\mathrm{A}_{4}$ through 5-LO activity (Figure 1). $\mathrm{LTA}_{4}$ is subsequently converted by $\mathrm{LTA}_{4}$ hydrolase into $\mathrm{LTB}_{4}$ and by $\mathrm{LTC}_{4}$ synthase, which conjugates reduced glutathione into $\mathrm{LTC}_{4}$. This is metabolized into $\mathrm{LTD}_{4}$, which is then metabolized into $\mathrm{LTE}_{4}$. $\mathrm{LTC}_{4}, \mathrm{LTD}_{4}$ and $\mathrm{LTE}_{4}$ are designated as cysteinyl leukotrienes (CysLTs). LTs are synthesized upon cellular activation and the intracellular expression and distribution of 5-LO varies considering the cell type. In the airways, 5-LO is present in several types of leukocytes and becomes activated during allergic inflammation [8]. CysLTs activate three receptors with differential selectivity (CysLT 1, CysLT $_{2}$ and GPR17) and the stimulation of these receptors, principally CysLT ${ }_{1}$, account for most of its effects [21]. This receptor is expressed in a large variety of cells which include monocytes, macrophages, eosinophils, basophils, mast cells, neutrophils, T cells, B lymphocytes, pluripotent hematopoietic cells, interstitial cells of the nasal mucosa (NM), airway smooth muscle cells, bronchial fibroblasts and vascular endothelial cells [28] and its activation contributes to most of the effects of CysLTs that are relevant to the pathophysiological changes observed in patients with asthma [8].

\section{Cyclooxygenase pathway}

AA can be metabolized through the COX pathway by the action of the COX enzymes (Figure 1). COX is a bifunctional enzyme with two active sites, one with $\mathrm{COX}$ activity that catalyzes the reduction of AA to form $\mathrm{PGG}_{2}$ and the other with peroxidase activity involved in the reduction of peroxidase group in $\mathrm{PGG}_{2}$ to hydroxyl group forming $\mathrm{PGH}_{2}$. These enzymes catalyze the reactions responsible for the production of several bioactive prostanoids, such as PGs, prostacyclins and thromboxane [29]. Studies show the presence of two isoforms of COX enzymes, namely COX-1 and COX-2. COX-1, the dominant source of prostanoids that serves a number of physiologic "housekeeping" functions, presents a uniform expression in almost all tissue and is generally considered constitutive 


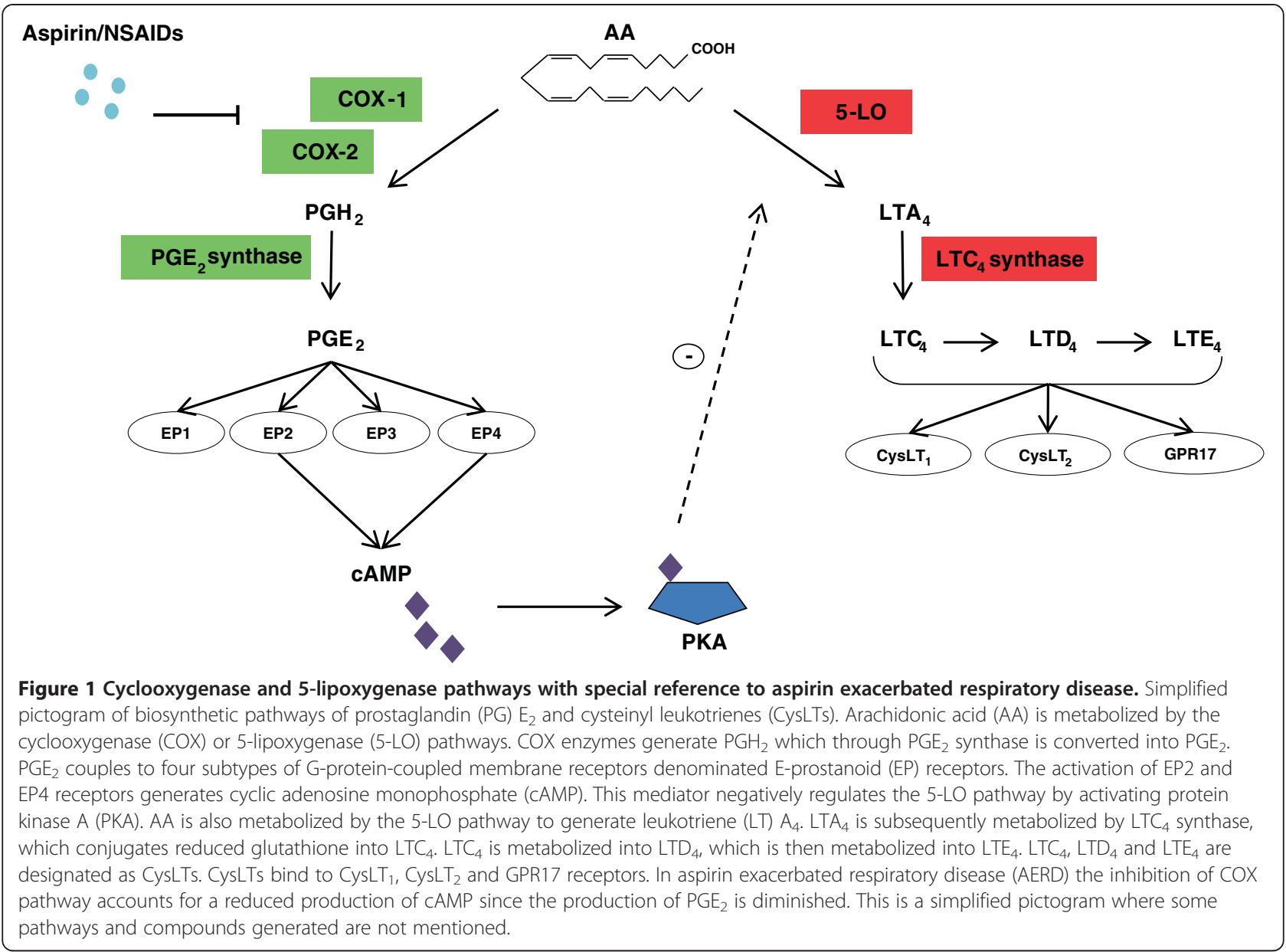

[30]. COX-2 is described, in diverse studies, as highly induced and only expressed in response to certain inflammatory stimuli [31-35]. Furthermore, COX-2 is the more important source of prostanoid formation in inflammatory processes and proliferative diseases [36]. Both isoforms are located in the endoplasmatic reticulum and nuclear envelope, COX-2 is more highly concentrated in the nuclear envelope [37]. $\mathrm{PGE}_{2}$ is one of the most abundant prostanoids produced in the body [36]. Montuschi and co-workers [38] evaluated the effects of COX inhibition on exhaled eicosanoids in patients with chronic obstructive pulmonary disease. The authors found that in exhaled breath condensate, $\mathrm{PGE}_{2}$ is primarily derived from COX-1 activity. $\mathrm{PGE}_{2}$ exhibits pleiotropic and contrasting effects in different cell types and organs. According to Vancheri $e t$ al. [39] the lung is considered a privileged site for the action of $\mathrm{PGE}_{2}$. Although in this organ $\mathrm{PGE}_{2}$ can exert antiinflammatory, anti-fibrotic and immune restrictive actions, it can also mediate pro-inflammatory responses $[39,40]$.

\section{Prostaglandin $\mathrm{E}_{2}$ receptors}

The activity of $\mathrm{PGE}_{2}$ is mediated by a group of rhodopsin-type G-protein-coupled membrane receptors
(GPCRs) denominated E-prostanoid (EP) receptors [41]. There are four GPCR subtypes: EP1, EP2, EP3 and EP4. The physiological and contrasting effects of $\mathrm{PGE}_{2}$ depend on the expression or the co-expression of more than one receptor or isoform [42]. Additionally, each receptor may be differentially expressed in tissues. EP receptors differ in terms of intracellular signalling [43,44]. These receptors could be classified according to their intracellular signalling and second messenger [45]. The EP1 receptor signals via $\mathrm{Ca}^{2+}$ mobilization with slight phosphatidylinositol activity [46,47]. Distribution of this receptor in human tissues and cells is restricted and has been demonstrated in the myometrium, pulmonary veins, mast cells, colonic longitudinal muscle and keratinocytes. EP1 exerts mostly constrictive functions, however and compared with other prostanoid receptors, it seems to be less studied [47]. EP2 and EP4 receptors increase intracellular cyclic adenosine monophosphate (cAMP) through activation of adenyl cyclase [39,48]. Functional studies have demonstrated that the EP2 receptor is widely distributed [49] and it seems to be involved in processes of relaxation such as bronchodilation [50] and anti-inflammation [51]. On the other hand, EP4 is also widely distributed 
[44]. In a direct comparison with EP2 receptor subtype signalling, the EP4 receptor demonstrated a less efficient functional coupling to cAMP [52,53]. Effectively, studies have reported several cAMP-independent signalling pathways for EP4 receptor activation [54-59]. EP4 mediates vasorelaxation of pulmonary arterial veins and also promotes anti-inflammatory effects [60]. Consistent with its bronchoprotective action, $\mathrm{PGE}_{2}$ inhibited proliferation and migration of bronchial smooth muscle cells through the action of the EP4 receptor [61]. Studies have revealed that the EP3 receptor shows a wide distribution in almost all tissues and consists of multiple isoforms generated by numerous alternative splicing of the C-terminal [62-64]. Signalling through this receptor reduces the levels of cAMP and increases intracellular $\mathrm{Ca}^{2+}$ [44]. EP3 exerts mainly contractile functions such as the constriction of human pulmonary artery in the lung [65]. Moreover, this receptor has been implicated in inflammation, pain and cough $[47,66]$.

In summary, EP2 and EP4 receptor signalling promotes the accumulation of cAMP which is normally related to inhibition of cell functions. On the other hand, EP1 and EP3 receptors that increase intracellular calcium could be associated with cellular activation.

\section{Arachidonic acid metabolism in aspirin exacerbated respiratory disease}

The pathogenesis of AERD is not fully understood but several studies have reported that the pathogenic mechanisms of this condition may be due, at least in part, to marked imbalance in eicosanoid metabolism possibly increasing and perpetuating the process of inflammation $[20,22,67]$. Aspirin and other NSAIDs block the COX pathway by acetylation of the COX enzyme and consequently inhibit conversion of AA to PG. The dependency on COX products to modulate and maintain homeostasis over 5-LO activity is a unique feature of AERD [68]. Effectively in this disorder the inhibition of COX-1 results in the overproduction of CysLTs. CysLTs are potent bronchoconstrictors that contribute to the pathophysiological changes observed in patients with asthma. CysLTs, by increasing pulmonary microvascular permeability and mucus hypersecretion can contribute to bronchial obstruction in asthmatic patients [69-72]. Diamant et al. [73] reported that the inhalation of CysLTs increases eosinophilia in sputum of asthmatic patients and induces the recruitment of eosinophils into the airway mucosa. Indeed, CysLTs might participate in the process of airway remodeling, including eosinophilic airway inflammation, airway smooth muscle cell hyperplasia, mucus gland hyperplasia, mucus hypersecretion, and fibrous collagen depositions [69,70]. Several studies have described the biological effects and the contribution of these lipid mediators in AERD. After challenging
AERD patients with oral, intravenous and intranasal aspirin treatments, the levels of CysLTs are significantly increased [74,75]. Moreover, patients with AERD excrete higher levels of $\mathrm{LTE}_{4}$ in their urine when compared with asthmatic patients without aspirin intolerance [76,77]. Pérez-Novo et al. [78] reported that the nasal tissue of patients with CRSwNP presents elevated levels of CysLTs when compared with NM from aspirin-tolerant (AT) asthmatic patients and this increased production is associated with the elevated expression of $\mathrm{LTC}_{4}$ synthase, the terminal enzyme in the production of CysLTs. In summary, the overproduction of CysLTs reported in AERD seems to play an important role in the pathogenesis of the disease, since the levels of this mediator are comparatively reduced in asthmatic patients without aspirin intolerance.

$\mathrm{PGE}_{2}$ formed from COX-dependent conversion of AA have demonstrated inhibitory effects on CysLTs production. $\mathrm{PGE}_{2}$ administration blocks bronchoconstriction and inhibits the increase in urinary $\mathrm{LTE}_{4}$ that occur with aspirin challenge in subjects with AERD $[79,80]$. Pharmacological studies suggest that most urinary $\mathrm{PGE}_{2}$ metabolites in AT asthmatic patients and healthy subjects derive from COX-2 [81]. Several studies have demonstrated that NP tissue from subjects with or without aspirin sensitivity shows impaired expression of COX-2 $[82,83]$ and hypermethylation of the $\mathrm{PGE}_{2}$ synthase (PTGES) gene in patients with AERD when compared with polyps from AT patients [84]. Moreover, experiments in vitro have shown a reduced production of $\mathrm{PGE}_{2}$ in epithelial cells from NPs [85], bronchial fibroblasts [86], and peripheral blood leukocytes from patients with AERD [87]. The combination of a reduced expression of COX-2 in inflammatory conditions in subjects with AERD with hypermethylation of the PTGES gene reported could be responsible for the low production of $\mathrm{PGE}_{2}$ observed in these subjects. Thereby, in patients with AERD, when COX-1 is inhibited by aspirin or other NSAIDs, the diminished availability of $\mathrm{PGE}_{2}$ will contribute to the exacerbations of the characteristic symptoms of this pathology.

\section{Prostaglandin $E_{2}$ receptors in asthma and chronic rhinosinusitis with nasal polyps}

Few studies have been performed to elucidate the importance of this receptor family in upper and lower respiratory airway diseases. The literature mainly describes the expression and cellular distribution of these receptors at different levels of the airways, using for that purpose diverse type of samples, such as biopsies, cultured cells or peripheral blood and different techniques.

\section{Asthma}

Additional file 1: Table S1 shows the main publications on EP receptors in asthma [see Additional file 1: Table 
S1]. Ying and co-workers [88] used immunocytochemistry to compare the expression and cellular distribution of the EP receptors in induced sputum cells from asthmatic patients and control subjects. They reported that sputum cells showed immunoreactivity for all receptors in both patients with asthma and control subjects. However, in patients with asthma, they found a high immunoreactivity for EP2 and EP4, but not EP1 and EP3 receptors on macrophages when compared with control subjects. The investigators concluded that the pattern of EP receptor expression is particularly increased in airway macrophages of patients with asthma.

In a study performed with bronchial biopsies [89] from both AERD and AT asthmatic patients and control subjects, the authors reported that, compared with AT, patients with AERD have increased bronchial mucosal neutrophil and eosinophil numbers but reduced percentages of $\mathrm{T}$ cells, macrophages, mast cells and neutrophils expressing EP2. In contrast, quantitative analysis of EP receptor mRNA expression in peripheral blood mononuclear cells isolated from these patients showed no significant differences between the two groups.

\section{Chronic rhinosinusitis and nasal polyps}

In Additional file 2: Table S2 we highlight the studies that have been performed to elucidate the importance of the EP receptors on the upper airways [see Additional file 2: Table S2]. Pérez-Novo et al. [90] studied the possible link between the expression of prostanoid receptors and the eosinophilic inflammation characteristic of paranasal sinus diseases by means of real-time PCR. The results of this study showed a high mRNA expression of EP2 and EP4 receptors in nasal tissue from both CRS without NP (CRSsNP) and CRSwNP patients when compared with control subjects. On the other hand, EP1 and EP3 receptors seem to be downregulated in nasal tissue from CRSwNP when compared with CRSsNP patients and control subjects.

Ying and co-workers [91], in a study based on immunohistochemistry, analysed the expression pattern of EP receptors in nasal biopsies from CRSwNP patients with AERD and AT and control subjects. The extensive analysis showed that, globally, mucosal expression of EP1 and EP2, but not EP3 and EP4 was significantly elevated in nasal biopsies from both patients with AERD and AT patients when compared with nasal biopsies extracted from control subjects. The researchers attribute the results principally to the high percentage of epithelial cells and goblet cells expressing these receptors. In inflammatory cells, the findings reported were different. They showed that the percentages of neutrophils, mast cells, eosinophils and T cells expressing EP2, but not EP1, EP3, or EP4, were significantly reduced in AERD patients when compared with AT patients.
Effectively, EP2 receptor downregulation seems to be common in both upper and lower airways of patients with AERD. Adamusiak and collaborators [92] described that, in NPs from AERD patients, the density of cells expressing the EP2 receptor was significantly lower when compared with NP from AT patients.

Using the Western blot technique, Roca-Ferrer et al. [83], using fibroblast cell cultures isolated from NP of both AERD and AT patients, described that there were low levels of EP2 protein receptor expression under inflammatory conditions when compared with fibroblasts isolated from NM of control subjects.

Apart from these expression studies, various polymorphisms in EP2 gene (PTGER2) were described [93,94] and they could possibly be related to AERD. In an extensive candidate gene analysis study to identify susceptibilities to AERD in the Japanese population, Jinnai and coworkers [93] showed the association of AERD with a functional single-nucleotide polymorphism in PTGER2 that decreases the transcription level of the receptor in vitro.

As previously described, the ability of $\mathrm{PGE}_{2}$ to induce or suppress various mechanisms involved in inflammatory processes indicates the complex activities of its receptor. The activation of EP2 and EP4 (Figure 1) initiates the production of cAMP, a secondary messenger that acts by activating protein kinase A (PKA). Once activated, PKA has the capacity to regulate 5-LO [95,96] by phosphorylation of serine-523 in 5-LO, suppressing its function. Effectively, Luo and co-workers [96] described that the mutation of serine-523 on human 5-LO prevents phosphorylation by PKA and promotes the abnormal synthesis of LTs. The dysfunctional signalling through cAMP and PKA contributes to a variety of diseases, including those characterized by chronic inflammation. In 1983, Ham and colleagues [97] showed for the first time that $\mathrm{PGE}_{2}$ inhibited LT biosynthesis in activated neutrophils, and the inhibition was mediated by an increment of cAMP levels. Indeed, the mechanisms by which the enhancement of cAMP (by $\mathrm{PGE}_{2}$ or other cAMP-elevating agents) are able to down-regulate LT biosynthesis involve the inhibition of the translocation of 5-LO to the nuclear envelope in human polymorphonuclear leukocytes [80]. The mechanisms and receptors by which $\mathrm{PGE}_{2}$ modulates the activation of human mast cells have also been assessed [95]. The investigators described that $\mathrm{PGE}_{2}$ can attenuate through EP2 receptors the generation of CysLTs in activated mast cells. The effect of low levels of EP2 on the downstream signalling pathway as well as the polymorphic variants of its gene are still unclear and further studies are needed to determine the functional repercussion of these alterations. Nevertheless, considering the regulatory effect of $\mathrm{PGE}_{2}$ on 5-LO through EP2 receptors these alterations could 
contribute, at least in part, to the exacerbation of the inflammatory processes demonstrated in patients with AERD.

\section{Targeting prostaglandin $\mathrm{E}_{2}$ receptors}

All the available information about the role of EP receptor subtypes in inflammatory airway diseases or in a totally different disorder comes partly from genetic ablation of prostanoid receptors or from studies performed with selective EP receptor agonists or antagonists. The latter strategy includes the development of small-molecule ligands that target a specific EP receptor and whose purpose is receptor inhibition or activation. All EP receptors are activated by their natural agonist $\mathrm{PGE}_{2}$ or by a number of $\mathrm{PGE}_{2}$ analogues named agonists and inhibited by antagonists. Over the years several studies have been performed to develop these compounds, which are used to find a possible therapeutic approach to treat numerous diseases [47].

As described previously, the EP2 receptor exerts many inhibitory functions. $\mathrm{PGE}_{2}$ has been considered to be a bronchodilator and anti-inflammatory natural substance with potential for treating asthma and other respiratory diseases. The use of developed selective agonists improved this viewpoint. Effectively, the bronchodilator effect of $\mathrm{PGE}_{2}$ is mediated by the EP2 receptor, which promotes airway relaxation and inhibits IgE-dependent mast cell activation [98]. Recent studies have also shown that the EP4 receptor mediates bronchodilation supporting the idea that targeting this receptor may be a novel therapeutic approach for obstructive airway diseases [99]. Patients with AERD characteristically showed a critical deficiency in $\mathrm{PGE}_{2} / \mathrm{EP} 2$ signalling. Considering the protective and beneficial effects of the $\mathrm{PGE}_{2} / \mathrm{EP} 2$ axis in airways, the use of specific commercially developed agonists could correct this deficit and ameliorate the inflammation scenario in these patients. The potential use of inhibitors of the EP3 receptor in the treatment of chronic cough has also been recently proposed [66].

\section{Conclusions}

Differential regulation and expression patterns of $\mathrm{PGE}_{2}$ receptors were observed in each of the chronic inflammatory airway diseases presented in this review. Although these alterations may worsen the already diminished levels of $\mathrm{PGE}_{2}$, additional studies are necessary to reveal further information about the role of these receptors in asthma and CRS with or without NPs or aspirin hypersensitivity. Moreover, EP receptors represent potential targets for therapeutic approaches. The use of $\mathrm{PGE}_{2}$ analogues and synthetic drugs, which can selectively and specifically agonize or antagonize signalling from EP receptor subtypes, has proved very useful for a deeper understanding of the pathologic mechanisms where $\mathrm{PGE}_{2}$ and its receptors are involved.

\section{Additional files}

Additional file 1: Table S1. Prostaglandin $E_{2}$ receptor expression in lower airways.

Additional file 2: Table S2. Prostaglandin $E_{2}$ receptor expression in upper airways.

\section{Abbreviations}

AA: Arachidonic acid; AERD: Aspirin exacerbated respiratory disease; AT: Aspirintolerant; CAMP: Cyclic adenosine monophosphate; COX: Cyclooxygenase; CRS: Chronic rhinosinusitis; CRSwNP: Chronic rhinosinusitis with nasal polyp; CRSsNP: Chronic rhinosinusitis without nasal polyp; CysLTs: Cysteinyl leukotrienes; EP: E-prostanoid; GPCR: G-protein-coupled membrane receptor Ig: Immunoglobulin; IL: Interleukin; LO: Lipoxygenase; LT: Leukotriene; NM: Nasal mucosa; NP: Nasal polyp; NSAID: Non-steroidal anti-inflammatory drug; PG: Prostaglandin; PKA: Protein kinase A; Th: T helper.

\section{Competing interests}

The authors declared that there are no competing interests in relation to this manuscript.

\section{Authors' contributions}

All authors wrote and revised the manuscript, and approved the final version.

\section{Acknowledgements}

LMC was supported by a grant from the Centro de Investigaciones Biomédicas en Red de Enfermedades Respiratorias from Instituto de Salud Carlos III, Madrid, Spain.

\section{Author details}

${ }^{1}$ Immunoal · lèrgia Respiratòria Clínica i Experimental, CELLEX, Institut d'Investigacions Biomèdiques August Pi i Sunyer (IDIBAPS), Casanova 143, 08036 Barcelona, Spain. ${ }^{2}$ Servei de Pneumologia i Al · lèrgia Respiratòria, Hospital Clínic, Universitat de Barcelona, Barcelona, Spain. ${ }^{3}$ Centro de Investigaciones Biomédicas en Red de Enfermedades Respiratorias (CIBERES), Instituto de Salud Carlos III, Madrid, Spain.

Received: 23 April 2014 Accepted: 13 August 2014

Published: 26 August 2014

\section{References}

1. Fireman P: Understanding asthma pathophysiology. Allergy Asthma Proc 2003, 24:79-83.

2. Eisenbarth SC, Cassel S, Bottomly K: Understanding asthma pathogenesis: linking innate and adaptive immunity. Curr Opin Pediatr 2004, 16:659-666.

3. Schreck DM: Asthma pathophysiology and evidence-based treatment of severe exacerbations. Am J Health Syst Pharm 2006, 63(10 Suppl 3):5-13.

4. Murphy DM, O'Byrne PM: Recent advances in the pathophysiology of asthma. Chest 2010, 137:1417-1426.

5. Montuschi P, Barnes PJ: New perspectives in pharmacological treatment of mild persistent asthma. Drug Discov Today 2011, 16:1084-1091.

6. Corren J: Asthma phenotypes and endotypes: an evolving paradigm for classification. Discov Med 2013, 15:243-249.

7. Pekkanen J, Lampi J, Genuneit J, Hartikainen AL, Järvelin MR: Analyzing atopic and non-atopic asthma. Eur J Epidemiol 2012, 27:281-286.

8. Montuschi P, Sala A, Dahlén SE, Folco G: Pharmacological modulation of the leukotriene pathway in allergic airway disease. Drug Discov Today 2007, 12:404-412.

9. Fokkens WJ, Lund VJ, Mullol J, Bachert C, Alobid I, Baroody F, Cohen N, Cervin A, Douglas R, Gevaert P, Georgalas C, Goossens H, Harvey R, Hellings P, Hopkins C, Jones N, Joos G, Kalogjera L, Kern B, Kowalski M, Price D, Riechelmann H, Schlosser R, Senior B, Thomas M, Toskala E, Voegels R, De Wang Y, Wormald PJ, EPOS: European position paper on rhinosinusitis and nasal polyps 2012: a summary for otorhinolaryngologists. Rhinology 2012, 50:1-12.

10. Benninger MS, Ferguson BJ, Hadley JA, Hamilos DL, Jacobs M, Kennedy DW, Lanza DC, Marple BF, Osguthorpe JD, Stankiewicz JA, Anon J, Denneny J, Emanuel I, Levine $\mathrm{H}$ : Adult chronic rhinosinusitis: definitions, diagnosis, epidemiology, and pathophysiology. Otolaryngol Head Neck Surg 2003, 129(Suppl 3):S1-S32. 
11. Masood A, Moumoulidis I, Panesar J: Acute rhinosinusitis in adults: an update on current management. Postgrad Med J 2007, 83:402-408.

12. Fokkens $W$, Lund $V$, Bachert $C$, Clement $P$, Helllings $P$, Holmstrom $M$, Jones N, Kalogjera L, Kennedy D, Kowalski M, Malmberg H, Mullol J, Passali D, Stammberger $\mathrm{H}$, Stierna P: EAACl position paper on rhinosinusitis and nasal polyps executive summary. Allergy 2005, 60:583-601.

13. Akdis CA, Bachert C, Cingi C, Dykewicz MS, Hellings PW, Naclerio RM, Schleimer RP, Ledford D: Endotypes and phenotypes of chronic rhinosinusitis: a PRACTALL document of the European Academy of Allergy and Clinical Immunology and the American Academy of Allergy, Asthma \& Immunology. J Allergy Clin Immunol 2013, 131:1479-1490.

14. Pawankar R: Nasal polyposis: an update: editorial review. Curr Opin Allergy Clin Immunol 2003, 3:1-6.

15. Fokkens W, Lund V, Mullol J, European Position Paper on Rhinosinusitis and Nasal Polyps group: European position paper on rhinosinusitis and nasal polyps 2007. Rhinol Supp/ 2007, 20:1-136

16. Pawankar R, Nonaka M: Inflammatory mechanisms and remodeling in chronic rhinosinusitis and nasal polyps. Curr Allergy Asthma Rep 2007, 7:202-208.

17. Chang HS, Park JS, Jang AS, Park SW, Uh ST, Kim YH, Park CS: Diagnostic value of clinical parameters in the prediction of aspirin-exacerbated respiratory disease in asthma. Allergy Asthma Immunol Res 2011, 3:256-264.

18. Lee RU, Stevenson DD: Aspirin-exacerbated respiratory disease: evaluation and management. Allergy Asthma Immunol Res 2011, 1:3-10.

19. Choi JH, Kim MA, Park HS: An update on the pathogenesis of the upper airways in aspirin-exacerbated respiratory disease. Curr Opin Allergy Clin Immunol 2014, 14:1-6.

20. Stevenson DD, Szczeklik A: Clinical and pathologic perspectives on aspirin sensitivity and asthma. J Allergy Clin Immunol 2006, 118:773-786.

21. Narayanankutty A, Reséndiz-Hernández JM, Falfán-Valencia R, Teran LM: Biochemical pathogenesis of aspirin exacerbated respiratory disease (AERD). Clin Biochem 2013, 46:566-578.

22. Mascia K, Haselkorn T, Deniz YM, Miller DP, Bleecker ER, Borish L, TENOR Study Group: Aspirin sensitivity and severity of asthma: evidence for irreversible airway obstruction in patients with severe or difficult-to-treat asthma. J Allergy Clin Immunol 2005, 116:970-975.

23. Mullol J, Picado C: Rhinosinusitis and nasal polyps in aspirin-exacerbated respiratory disease. Immunol Allergy Clin North Am 2013, 33:163-176.

24. Laidlaw TM, Boyce JA: Pathogenesis of aspirin-exacerbated respiratory disease and reactions. Immunol Allergy Clin North Am 2013, 33:195-210.

25. Chilton FH, Rudel LL, Parks JS, Arm JP, Seeds MC: Mechanisms by which botanical lipids affect inflammatory disorders. Am J Clin Nutr 2008, 87:498S-503S

26. Ghosh M, Tucker DE, Burchett SA, Leslie CC: Properties of the Group IV phospholipase A2 family. Prog Lipid Res 2006, 45:487-510.

27. Folco G, Murphy RC: Eicosanoid transcellular biosynthesis: from cell-cell interactions to in vivo tissue responses. Pharmacol Rev 2006, 58:375-388

28. Montuschi P: Leukotrienes, antileukotrienes and asthma. Mini Rev Med Chem 2008, 8:647-656

29. Smith WL, DeWitt DL, Garavito RM: Cyclooxygenases: structural, cellular, and molecular biology. Annu Rev Biochem 2000, 69:145-182.

30. Simmons DL, Botting RM, Hla T: Cyclooxygenase isozymes: the biology of prostaglandin synthesis and inhibition. Pharmacol Rev 2004, 56:387-437.

31. Siegle I, Klein T, Backman JT, Saal JG, Nüsing RM, Fritz P: Expression of cyclooxygenase 1 and cyclooxygenase 2 in human synovial tissue: differential elevation of cyclooxygenase 2 in inflammatory joint diseases. Arthritis Rheum 1998, 41:122-129.

32. Lohinai Z, Stachlewitz R, Székely AD, Fehér E, Dézsi L, Szabó C: Evidence for the expression of cyclooxygenase-2 enzyme in periodontitis. Life Sci 2001, 70:279-290

33. Roca-Ferrer J, Pujols L, Gartner S, Moreno A, Pumarola F, Mullol J, Cobos N, Picado C: Upregulation of COX-1 and COX-2 in nasal polyps in cystic fibrosis. Thorax 2006, 61:592-596.

34. Xaubet A, Roca-Ferrer J, Pujols L, Ramírez J, Mullol J, Marin-Arguedas A, Torrego A, Gimferrer JM, Picado C: Cyclooxygenase-2 is up-regulated in lung parenchyma of chronic obstructive pulmonary disease and downregulated in idiopathic pulmonary fibrosis. Sarcoidosis Vasc Diffuse Lung Dis 2004, 21:35-42.

35. Togo S, Holz O, Liu X, Sugiura H, Kamio K, Wang X, Kawasaki S, Ahn Y, Fredriksson K, Skold CM, Mueller KC, Branscheid D, Welker L, Watz H,
Magnussen $\mathrm{H}$, Rennard SI: Lung fibroblast repair functions in patients with chronic obstructive pulmonary disease are altered by multiple mechanisms. Am J Respir Crit Care Med 2008, 178:248-260.

36. Ricciotti E, FitzGerald GA: Prostaglandins and inflammation. Arterioscler Thromb Vasc Biol 2011, 31:986-1000

37. Morita I, Schindler M, Regier MK, Otto JC, Hori T, DeWitt DL, Smith WL: Different intracellular locations for prostaglandin endoperoxide $\mathrm{H}$ synthase-1 and -2. J Biol Chem 1995, 270:10902-10908.

38. Montuschi P, Macagno F, Parente P, Valente S, Lauriola L, Ciappi G, Kharitonov SA, Barnes PJ, Ciabattoni G: Effects of cyclo-oxygenase inhibition on exhaled eicosanoids in patients with COPD. Thorax 2005, 60:827-833.

39. Vancheri C, Mastruzzo C, Sortino MA, Crimi N: The lung as a privileged site for the beneficial actions of PGE2. Trends Immunol 2004, 25:40-46.

40. Bauman KA, Wettlaufer SH, Okunishi K, Vannella KM, Stoolman JS, Huang SK, Courey AJ, White ES, Hogaboam CM, Simon RH, Toews GB, Sisson TH, Moore BB, Peters-Golden M: The antifibrotic effects of plasminogen activation occur via prostaglandin E2 synthesis in humans and mice. J Clin Invest 2010, 120:1950-1960.

41. Sugimoto Y, Narumiya S: Prostaglandin E receptors. J Biol Chem 2007, 282:11613-11617

42. Rocca B: Targeting PGE2 receptor subtypes rather than cyclooxygenases: a bridge over troubled water? Mol Interv 2006, 6:68-73.

43. Narumiya S: Prostanoid receptors: structure, function, and distribution Ann N Y Acad Sci 1994, 744:126-138

44. Narumiya S, Sugimoto Y, Ushikubi F: Prostanoid receptors: structures, properties, and functions. Physiol Rev 1999, 79:1193-1226.

45. Norel X, Walch L, Labat C, Gascard JP, Dulmet E, Brink C: Prostanoid receptors involved in the relaxation of human bronchial preparations. Br J Pharmacol 1999, 126:867-872

46. Watabe A, Sugimoto $Y$, Honda A, Irie A, Namba T, Negishi M, Ito S, Narumiya S, Ichikawa A: Cloning and expression of CDNA for a mouse EP1 subtype of prostaglandin E receptor. J Biol Chem 1993, 268:20175-20178.

47. Woodward DF, Jones RL, Narumiya S: International union of basic and clinical pharmacology: LXXXIII: classification of prostanoid receptors, updating 15 years of progress. Pharmacol Rev 2011, 63:471-538.

48. Regan JW, Bailey TJ, Pepperl DJ, Pierce KL, Bogardus AM, Donello JE, Fairbairn CE, Kedzie KM, Woodward DF, Gil DW: Cloning of a novel human prostaglandin receptor with characteristics of the pharmacologically defined EP2 subtype. Mol Pharmacol 1994, 46:213-220.

49. Coleman RA, Smith WL, Narumiya S: International Union of Pharmacology classification of prostanoid receptors: properties, distribution, and structure of the receptors and their subtypes. Pharmacol Rev 1994 46:205-229.

50. Kay LJ, Yeo WW, Peachell PT: Prostaglandin E2 activates EP2 receptors to inhibit human lung mast cell degranulation. Br J Pharmacol 2006, 147:707-713.

51. Takayama K, García-Cardena G, Sukhova GK, Comander J, Gimbrone MA Jr, Libby P: Prostaglandin E2 suppresses chemokine production in human macrophages through the EP4 receptor. J Bio/ Chem 2002, 277:44147-44154.

52. Fujino $H$, West KA, Regan JW: Phosphorylation of glycogen synthase kinase-3 and stimulation of T-cell factor signalling following activation of EP2 and EP4 prostanoid receptors by prostaglandin E2. J Biol Chem 2002, 277:2614-2619.

53. Fujino H, Salvi S, Regan JW: Differential regulation of phosphorylation of the CAMP response element-binding protein after activation of EP2 and EP4 prostanoid receptors by prostaglandin E2. Mol Pharmacol 2005, 68:251-259.

54. Fiebich BL, Schleicher S, Spleiss O, Czygan M, Hüll M: Mechanisms of prostaglandin E2-induced interleukin-6 release in astrocytes: possible involvement of EP4-like receptors, p38 mitogen-activated protein kinase and protein kinase C. J Neurochem 2001, 79:950-958.

55. Pozzi A, Yan X, Macias-Perez I, Wei S, Hata AN, Breyer RM, Morrow JD, Capdevila $\mathrm{JH}$ : Colon carcinoma cell growth is associated with prostaglandin E2/EP4 receptor-evoked ERK activation. J Biol Chem 2004, 279:29797-29804.

56. Mendez M, LaPointe MC: PGE2-induced hypertrophy of cardiac myocytes involves EP4 receptor-dependent activation of p42/44 MAPK and EGFR transactivation. Am J Physiol Heart Circ Physiol 2005, 288:H2111-H2117.

57. Frias MA, Rebsamen MC, Gerber-Wicht C, Lang U: Prostaglandin E2 activates Stat3 in neonatal rat ventricular cardiomyocytes: a role in cardiac hypertrophy. Cardiovasc Res 2007, 73:57-65. 
58. George RJ, Sturmoski MA, Anant S, Houchen CW: EP4 mediates PGE2 dependent cell survival through the PI3 kinase/AKT pathway. Prostaglandins Other Lipid Mediat 2007, 83:112-120.

59. Rao R, Redha R, Macias-Perez I, Su Y, Hao C, Zent R, Breyer MD, Pozzi A: Prostaglandin E2-EP4 receptor promotes endothelial cell migration via ERK activation and angiogenesis in vivo. J Biol Chem 2007, 282:16959-16968.

60. Foudi N, Kotelevets L, Louedec L, Leséche G, Henin D, Chastre E, Norel X: Vasorelaxation induced by prostaglandin E2 in human pulmonary vein: role of the EP4 receptor subtype. Br J Pharmacol 2008, 154:1631-1639.

61. Aso H, Ito S, Mori A, Suganuma N, Morioka M, Takahara N, Kondo M, Hasegawa Y: Differential regulation of airway smooth muscle cell migration by E-prostanoid receptor subtypes. Am J Respir Cell Mol Biol 2013, 48:322-329.

62. Sugimoto $Y$, Negishi $M$, Hayashi $Y$, Namba $T$, Honda A, Watabe A, Hirata M, Narumiya S, Ichikawa A: Two isoforms of the EP3 receptor with different carboxyl-terminal domains. Identical ligand binding properties and different coupling properties with Gi proteins. J Biol Chem 1993, 268:2712-2718.

63. Schmid A, Thierauch $\mathrm{KH}$, Schleuning WD, Dinter $\mathrm{H}$ : Splice variants of the human EP3 receptor for prostaglandin E2. Eur J Biochem 1995, 228:23-30.

64. Kotelevets L, Foudi N, Louedec L, Couvelard A, Chastre E, Norel X: A new mRNA splice variant coding for the human EP3-I receptor isoform. Prostaglandins Leukot Essent Fatty Acids 2007, 77:195-201.

65. Qian YM, Jones RL, Chan KM, Stock Al, Ho JK: Potent contractile actions of prostanoid EP3-receptor agonists on human isolated pulmonary artery. Br J Pharmacol 1994, 113:369-374.

66. Maher SA, Birrell MA, Belvisi M: Prostaglandn E2 mediates cough via the EP3 receptor. Implications for future disease therapy. Am J Respir Crit Care Med 2009, 180:923-928.

67. Kim SH, Kim YK, Park HW, Jee YK, Kim SH, Bahn JW, Chang YS, Kim SH, Ye YM, Shin ES, Lee JE, Park HS, Min KU: Association between polymorphisms in prostanoid receptor genes and aspirin-intolerant asthma. Pharmacogenet Genomics 2007, 17:295-304.

68. Liu T, Laidlaw TM, Katz HR, Boyce JA: Prostaglandin E2 deficiency causes a phenotype of aspirin sensitivity that depends on platelets and cysteinyl leukotrienes. Proc Natl Acad Sci U S A 2013, 110:16987-16992.

69. Montuschi P, Peters-Golden ML: Leukotriene modifiers for asthma treatment. Clin Exp Allergy 2010, 40:1732-1741.

70. Montuschi P, Santini G, Valente S, Mondino C, Macagno F, Cattani P, Zini G, Mores $\mathrm{N}$ : Liquid chromatography-mass spectrometry measurement of leukotrienes in asthma and other respiratory diseases. J Chromatogr B Analyt Technol Biomed Life Sci 2014, 964:12-25.

71. Lewis RA, Austen KF, Soberman RJ: Leukotrienes and other products of the 5-lipoxygenase pathway: biochemistry and relation to pathobiology in human diseases. N Engl J Med 1990, 323:645-655.

72. Henderson WR: The role of leukotrienes in inflammation. Ann Intern Med 1994, 121:684-697.

73. Diamant Z, Hiltermann JT, van Rensen EL, Callenbach PM, Veselic-Charvat M, van der Veen H, Sont JK, Sterk PJ: The effect of inhaled leukotriene D4 and methacholine on sputum cell differentials in asthma. Am J Respir Crit Care Med 1997, 155:1247-1253.

74. Picado C, Ramis I, Rosellò J, Prat J, Bulbena O, Plaza V, Montserrat JM, Gelpí E: Release of peptide leukotriene into nasal secretions after local instillation of aspirin in aspirin-sensitive asthmatic patients. Am Rev Respir Dis 1992, 145:65-69.

75. Micheletto C, Tognella S, Visconti M, Trevisan F, Dal Negro RW: Changes in urinary LTE4 and nasal functions following nasal provocation test with ASA in ASA-tolerant and -intolerant asthmatics. Respir Med 2006, 100:2144-2150.

76. Smith CM, Hawksworth RJ, Thien FC, Christie PE, Lee TH: Urinary leukotriene E4 in bronchial asthma. Eur Respir J 1992, 5:693-699.

77. Higashi N, Taniguchi M, Mita H, Yamaguchi H, Ono E, Akiyama K: Aspirinintolerant asthma (AIA) assessment using the urinary biomarkers, leukotriene E4 (LTE4) and prostaglandin D2 (PGD2) metabolites. Allergol Int 2012, 61:393-403.

78. Pérez-Novo CA, Watelet JB, Claeys C, Van Cauwenberge P, Bachert C: Prostaglandin, leukotriene, and lipoxin balance in chronic rhinosinusitis with and without nasal polyposis. J Allergy Clin Immunol 2005, 115:1189-1196.

79. Sestini P, Armetti L, Gambaro G, Pieroni MG, Refini RM, Sala A, Vaghi A Folco GC, Bianco S, Robuschi M: Inhaled PGE2 prevents aspirin-induced bronchoconstriction and urinary LTE4 excretion in aspirin-sensitive asthma. Am J Respir Crit Care Med 1996, 153:572-575.

80. Flamand N, Surette ME, Picard S, Bourgoin S, Borgeat P: Cyclic AMPmediated inhibition of 5-lipoxygenase translocation and leukotriene biosynthesis in human neutrophils. Mol Pharmacol 2002, 62:250-256.

81. Duffield-Lillico AJ, Boyle JO, Zhou XK, Ghosh A, Butala GS, Subbaramaiah K, Newman RA, Morrow JD, Milne GL, Dannenberg AJ: Levels of prostaglandin $\mathrm{E}$ metabolite and leukotriene $\mathrm{E}(4)$ are increased in the urine of smokers: evidence that celecoxib shunts arachidonic acid into the 5-lipoxygenase pathway. Cancer Prev Res (Phila) 2009, 2:322-329.

82. Picado C, Fernandez-Morata JC, Juan M, Roca-Ferrer J, Fuentes M, Xaubet A, Mullol J: Cyclooxygenase-2 mRNA is downexpressed in nasal polyps from aspirin-sensitive asthmatics. Am J Respir Crit Care Med 1999, 160:291-296.

83. Roca-Ferrer J, Garcia-Garcia FJ, Pereda J, Perez-Gonzalez M, Pujols L, Alobid I, Mullol J, Picado C: Reduced expression of COXs and production of prostaglandin $\mathrm{E}(2)$ in patients with nasal polyps with or without aspirin-intolerant asthma. J Allergy Clin Immunol 2011, 128:66-72.

84. Cheong HS, Park SM, Kim MO, Park JS, Lee JY, Byun JY, Park BL, Shin HD Park CS: Genome-wide methylation profile of nasal polyps: relation to aspirin hypersensitivity in asthmatics. Allergy 2011, 66:637-644.

85. Kowalski ML, Pawliczak R, Wozniak J, Siuda K, Poniatowska M, Iwaszkiewicz J, Kornatowski T, Kaliner MA: Differential metabolism of arachidonic acid in nasal polyp epithelial cells cultured from aspirin-sensitive and aspirin-tolerant patients. Am J Respir Crit Care Med 2000, 161:391-398.

86. Pierzchalska M, Szabó Z, Sanak M, Soja J, Szczeklik A: Deficient prostaglandin E2 production by bronchial fibroblasts of asthmatic patients, with special reference to aspirin-induced asthma. J Allergy Clin Immunol 2003, 111:1041-1048.

87. Jedrzejczak-Czechowicz M, Lewandowska-Polak A, Bienkiewicz B, Kowalski $\mathrm{ML}$ : Involvement of 15-lipoxygenase and prostaglandin EP receptors in aspirin-triggered 15-hydroxyeicosatetraenoic acid generation in aspirin-sensitive asthmatics. Clin Exp Allergy 2008, 38:1108-1116.

88. Ying S, O'Connor BJ, Meng Q, Woodman N, Greenaway S, Wong H, Mallett $\mathrm{K}$, Lee $\mathrm{TH}$, Corrigan C: Expression of prostaglandin $\mathrm{E}(2)$ receptor subtypes on cells in sputum from patients with asthma and controls: effect of allergen inhalational challenge. J Allergy Clin Immunol 2004, 114:1309-1316

89. Corrigan CJ, Napoli RL, Meng Q, Fang C, Wu H, Tochiki K, Reay V, Lee TH, Ying S: Reduced expression of the prostaglandin E2 receptor Eprostanoid 2 on bronchial mucosal leukocytes in patients with aspirin-sensitive asthma. J Allergy Clin Immunol 2012, 129:1636-1646.

90. Pérez-Novo CA, Claeys C, Van Cauwenberge P, Bachert C: Expression of eicosanoid receptors subtypes and eosinophilic inflammation: implication on chronic rhinosinusitis. Respir Res 2006, 7:75

91. Ying S, Meng Q, Scadding G, Parikh A, Corrigan CJ, Lee TH: Aspirinsensitive rhinosinusitis is associated with reduced E-prostanoid 2 receptor expression on nasal mucosal inflammatory cells. J Allergy Clin Immunol 2006, 117:312-318.

92. Adamusiak AM, Stasikowska-Kanicka O, Lewandowska-Polak A, Danilewicz M, Wagrowska-Danilewicz M, Jankowski A, Kowalski ML, Pawliczak R: Expression of arachidonate metabolism enzymes and receptors in nasal polyps of aspirin-hypersensitive asthmatics. Int Arch Allergy Immunol 2012, 157:354-362.

93. Jinnai N, Sakagami T, Sekigawa T, Kakihara M, Nakajima T, Yoshida K, Goto S, Hasegawa T, Koshino T, Hasegawa Y, Inoue H, Suzuki N, Sano Y, Inoue I: Polymorphisms in the prostaglandin E2 receptor subtype 2 gene confer susceptibility to aspirin-intolerant asthma: a candidate gene approach. Hum Mol Genet 2004, 13:3203-3217.

94. Kim SH, Park HS: Genetic markers for differentiating aspirinhypersensitivity. Yonsei Med J 2006, 47:15-21.

95. Feng C, Beller EM, Bagga S, Boyce JA: Human mast cells express multiple EP receptors for prostaglandin E2 that differentially modulate activation responses. Blood 2006, 107:3243-3250.

96. Luo M, Jones SM, Phare SM, Coffey MJ, Peters-Golden M, Brock TG: Protein kinase $A$ inhibits leukotriene synthesis by phosphorylation of 5 lipoxygenase on serine 523. J Biol Chem 2004, 279:41512-41520.

97. Ham EA, Soderman DD, Zanetti ME, Dougherty HW, McCauley E, Kuehl FA $\mathrm{Jr}$ : Inhibition by prostaglandins of leukotriene B4 release from activated neutrophils. Proc Natl Acad Sci U S A 1983, 80:4349-4353. 
98. Serra-Pages M, Olivera A, Torres R, Picado C, de Mora F, Rivera J: Eprostanoid 2 receptors dampen mas cell degranulation via cAMP/PKAmediated suppression of IgE-dependent signalling. J Leukoc Biol 2012, 92:1155-1165.

99. Benyahia C, Gomez I, Kanyinda L, Boukia K, Danel C, Leséche G, Longrois B, Norel X: PGE(2) receptor ((EP(4)) agonists: potent dilators of human bronchi and future asthma therapy? Pulmon Pharmacol Ther 2012, 25:115-118.

doi:10.1186/s12931-014-0100-7

Cite this article as: Machado-Carvalho et al:: Prostaglandin E2 receptors in asthma and in chronic rhinosinusitis/nasal polyps with and without aspirin hypersensitivity. Respiratory Research 2014 15:100.

\section{Submit your next manuscript to BioMed Central and take full advantage of:}

- Convenient online submission

- Thorough peer review

- No space constraints or color figure charges

- Immediate publication on acceptance

- Inclusion in PubMed, CAS, Scopus and Google Scholar

- Research which is freely available for redistribution 